\title{
Kombucha: A novel model system for cooperation and conflict in a complex multi-species microbial ecosystem
}

\author{
Alexander May ${ }^{1,2}$, Shrinath Narayanan ${ }^{3}$, Joe Alcock ${ }^{4}$, Arvind Varsani ${ }^{1,5,6,7}$, Carlo Maley ${ }^{1,3}$, Athena Aktipis ${ }^{\text {Corresp. } 2,3,7}$ \\ ${ }^{1}$ School of Life Sciences, Arizona State University, Tempe, Arizona, United States \\ 2 Department of Psychology, Arizona State University, Tempe, Arizona, United States \\ 3 The Biodesign Center for Biocomputing, Security and Society, Arizona State University, Tempe, Arizona, United States \\ 4 University of New Mexico, Albuquerque, New Mexico, United States \\ 5 The Biodesign Center for Fundamental and Applied Microbiomics, Center for Evolution and Medicine, School of Life Sciences, Arizona State University, \\ Tempe, United States \\ ${ }^{6}$ Structural Biology Research Unit, Department of Clinical Laboratory Sciences, University of Cape Town, Cape Town, South Africa \\ 7 Center for Evolution and Medicine, Arizona State University, Tempe, Arizona, United States \\ Corresponding Author: Athena Aktipis \\ Email address: aktipis@asu.edu
}

Kombucha, a fermented tea beverage with an acidic and effervescent taste, is composed of a multispecies microbial ecosystem with complex interactions that are characterized by both cooperation and conflict. In kombucha, a complex community of bacteria and yeast initiates the fermentation of a starter tea (usually black or green tea with sugar), producing a biofilm that covers the liquid over several weeks. This happens through several fermentative phases that are characterized by cooperation and competition among the microbes within the kombucha solution. Yeast produce invertase as a public good that enables both yeast and bacteria to metabolize sugars. Bacteria produce a surface biofilm which may act as a public good providing protection from invaders, storage for resources, and greater access to oxygen for microbes embedded within it. The ethanol and acid produced during the fermentative process (by yeast and bacteria, respectively) may also help to protect the system from invasion by microbial competitors from the environment. Thus, kombucha can serve as a model system for addressing important questions about the evolution of cooperation and conflict in diverse multispecies systems. Further, it has the potential to be artificially selected to specialize it for particular human uses, including the development of antimicrobial ecosystems and novel materials. Finally, kombucha is easily-propagated, non-toxic, and inexpensive, making it an excellent system for scientific inquiry and citizen science. 


\section{Kombucha: A novel model system for cooperation}

\section{2 and conflict in a complex multi-species microbial}

\section{3 ecosystem}

5 Alexander Niall May ${ }^{1,2}$, Shrinath Narayanan ${ }^{3}$, Joe Alcock ${ }^{4}$, Arvind Varsani1 ${ }^{1,5,6,7}$, Carlo Maley ${ }^{1,3}$,

6 Athena Aktipis $2,3,7$

7

$8{ }^{1}$ School of Life Sciences, Arizona State University, Tempe, Arizona, United States

$9 \quad 2$ Department of Psychology, Arizona State University, Tempe, Arizona, United States

$10{ }^{3}$ The Biodesign Center for Biocomputing, Security and Society, Arizona State University,

11 Tempe, Arizona, United States

$12{ }^{4}$ University of New Mexico, Albuquerque, New Mexico, United States

5 The Biodesign Center for Fundamental and Applied Microbiomics, Arizona State University,

14 Tempe, United States

${ }^{6}$ Structural Biology Research Unit, Department of Clinical Laboratory Sciences, University of

${ }^{7}$ Center for Evolution and Medicine, Arizona State University, Tempe, Arizona, United States

Corresponding Author:

21 Athena Aktipis $2,3,7$

PO Box 871104, Tempe, AZ 85287-1104, USA 
23 Email address: aktipis@asu.edu

\section{Abstract}

26 Kombucha, a fermented tea beverage with an acidic and effervescent taste, is composed of a

27 multispecies microbial ecosystem with complex interactions that are characterized by both cooperation and conflict. In kombucha, a complex community of bacteria and yeast initiates the fermentation of a starter tea (usually black or green tea with sugar), producing a biofilm that covers the liquid over several weeks. This happens through several fermentative phases that are characterized by cooperation and competition among the microbes within the kombucha solution. Yeast produce invertase as a public good that enables both yeast and bacteria to metabolize sugars. Bacteria produce a surface biofilm which may act as a public good providing

34 protection from invaders, storage for resources and greater access to oxygen for microbes embedded within it. The ethanol and acid produced during the fermentative process (by yeast and bacteria, respectively) may also help to protect the system from invasion by microbial competitors from the environment. Thus, kombucha can serve as a model system for addressing important questions about the evolution of cooperation and conflict in diverse multispecies systems. Further, it has the potential to be artificially selected to specialize it for particular human uses, including the development of antimicrobial ecosystems and novel materials. Finally,

41 kombucha is easily-propagated, non-toxic, and inexpensive, making it an excellent system for 42 scientific inquiry and citizen science.

\section{Introduction}


45 Kombucha is a traditional tea beverage fermented by a symbiotic community of acetic acid

46 bacteria (Acetobacteraceae) and osmophilic yeast (De Filippis et al., 2018). While the origins of

47 the beverage are uncertain, records of the drink are found in early 19th century Russia (Dufresne

$48 \&$ Farnworth, 2000). There is variation on the specifics of kombucha fermentation, but the

49 typical process proceeds as follows: black or green tea is brewed for at least five minutes,

50 supplemented with sucrose $(5 \%-10 \%(\mathrm{w} / \mathrm{v}))$, cooled to room temperature $\left(20^{\circ} \mathrm{C}\right)$, and then

51 inoculated with kombucha liquid (usually 10\%-20\% (v/v)) from a previous batch (Jayabalan et

52 al. 2014). A mature bacterial cellulose biofilm from a previously brewed kombucha culture

53 (often called a 'mother' or SCOBY, for Symbiotic Community of Bacteria and Yeast) is

54 typically placed on top of the solution and allowed to ferment for 10-14 days. The presence of a

55 carbon source in the solution, typically sucrose, initiates a cascade of metabolic processes that

56 generates a carbonated and slightly acidic drink at the end of the primary fermentation cycle.

57 One of the more striking aspects of the system is the floating cellulose pellicle that forms in

58 tandem with fermentation; this biofilm is produced by the bacteria and encapsulates a microbial

59 community within it (Marsh et al., 2014). The dominant bacterial genus in the system is

60 Komagataeibacter (formerly Gluconacetobacter, and prior to that, Acetobacter, Yamada et al.,

61 2012) (Marsh et al., 2014; Chakravoty et al., 2016) with numerous species identified within

62 various kombucha cultures. These include K. xylinus (Reva et al., 2015; De Filippis et al., 2018),

63 K. intermedius (Dos Santos et al., 2015; Reva et al., 2015; Gaggìa et al. 2019), K. rhaeticus

64 (Machado et al., 2016; Semjonovs et al., 2017; Gaggìa et al., 2019), K. saccharivorans (Reva et

65 al., 2015; De Filippis et al., 2018), and K. kombuchae (Reva et al., 2015). Another acetic acid

66 bacterial genus often found in kombucha cultures is Gluconobacter (Reva et al., 2015;

67 Chakravoty et al., 2016; Gaggìa et al., 2019). The yeast species in the system are even more 
68 variable, and can include yeast in the genera Zygosaccharomyces, Candida, Torulaspora, Pichia, 69 Brettanomyces/Dekkera, Schizosaccharomyces, and Saccharomyces (Mayser et al., 1995; Teoh,

70 Heard \& Cox, 2004; Marsh et al., 2014; Jayabalan et al., 2014; Reva et al., 2015). The microbial 71 profiles of kombucha seem to vary partly based on geographical origin (Mayser et al., 1995;

72 Marsh et al., 2014), and the composition of the kombucha changes over time as it progresses

73 through fermentation (Marsh et al., 2014). This process involves the enzymatic cleavage of

74 sucrose and the subsequent processing of its monomer components into ethanol, acids, cellulose,

75 and carbon dioxide (Jayabalan et al., 2014; Chakravorty et al., 2016). Brewed kombucha has

76 antimicrobial properties that persist even with neutralization of the solution to $\mathrm{pH} 7$ and thermal

77 denaturation at $80^{\circ} \mathrm{C}$ for 30 minutes (Sreeramulu, Zhu \& Knol, 2000).

78

79 In this manuscript, we describe the potential uses of kombucha as a model system for studying 80 cooperative and competitive interactions, and we also discuss the potential human uses of

81 kombucha and kombucha-generated biofilms for nutrition, human health and industrial 82 applications.

\section{Survey methodology}

85 This review was assembled via electronic searches on various platforms, including Google

86 Scholar, Web of Science, and PubMed. In order to gain a background understanding of

87 kombucha as a scientific model, searches were focused on the terminology adjacent to it and

88 other fermented foods: 'kombucha', 'kombucha tea', 'tea fungus', 'fermented tea',

89 'fermentation', 'SCOBY', 'biofilm', 'pellicle'. Examples of other fermented foods were

90 examined as well, particularly those already used as model systems, such as sourdough and 
91 yogurt. Further development of the literature collection used keywords associated with microbial

92

94

95 ecology and social interactions between microbes, such as: 'cooperation', 'conflict', 'symbiosis', 'syntrophy', 'cheater'.

Searches evolved to include aspects of the four phases of development known to occur during kombucha fermentation: invertase production, ethanol fermentation, ethanol oxidation and acidification, and biofilm formation; many of these sources primarily used other organism models as references. Each of these sources provided a wealth of data far beyond the scope of this paper, and thus were culled down to focus on the microorganisms reported within the kombucha community. As the kombucha scientific literature remains in its infancy, resources frequently led outside of the core focus of the paper and thus were integrated only as required.

\section{Microbial model systems help researchers address important}

\section{theoretical and applied questions}

There is a precedent for using model microbial systems for studying the evolution of cooperation, conflict and social behavior. Evolutionary biologists have used microbial systems to tackle ecology questions that would otherwise be unfeasible at a macroscale, such as exploring the selection pressures required for the evolution of cellular cooperation in the form of multicellularity (Strassmann, Zhu \& Queller, 2000; Ratcliff et al., 2012), as well as adaptive radiation, diversification, and population fragmentation (Rainey \& Travisano, 1998; Habets et al., 2006). Microbial model systems can be easily altered via genetic modifications and experimental evolution, and naturally produce many intriguing behavioral patterns - such as foraging, dispersal, collective assembly via biofilms, production of antagonistic chemicals, and 
114 quorum sensing (West et al., 2006), many of which resemble social processes among animals.

115 Microbial systems have also been used to address phenomena that were originally developed to 116 explain human interactions, such as the Prisoner's Dilemma (Greig \& Travisano, 2004) and the

117 Tragedy of the Commons (MacLean, 2008).

118

119 However, most existing microbial model systems consist of systems with single species or only a 120 few species. Artificial microbial systems can also be limited in their applicability to real world 121 phenomena and their scalability to larger ecological questions (Jessup et al., 2004). This is in 122 contrast to natural microbial systems, which are highly diverse and within which multispecies 123 cooperation is likely to be complex. Despite advances in the ability of microbiologists to bring

124 previously 'unculturable' microbes into the lab (Vartoukian, Palmer \& Wade, 2010) and the use 125 of metagenomics and other 'omics' approaches to analyze complex communities (Franzosa et al., 126 2015), the complexity of natural systems makes them difficult to reproduce and study in the 127 laboratory (Wolfe \& Dutton, 2015). We promote the idea that a compromise between natural and 128 artificial systems can be found in fermented foods. They provide the ease of culturing 129 microorganisms typical of simpler artificial systems, but include the diversity and complexity of natural systems. As a result, fermented foods and beverages may balance the advantages and 131 disadvantages of natural and artificial systems.

133 Methods for propagating many fermented cultures are well-characterized due to their long 134 history of cultivation and domestication. Genetic information exists for many of the microbes 135 that are key to these fermentation processes and they have predictable cycles of development and 136 succession, allowing for highly reproducible results despite their relative complexity (Wolfe \& 
137 Dutton, 2015). During decades or centuries of domestication, artificial selection also likely

138 favored fermented foods with cultures that are resistant to invasion by pathogenic species. The

139 microbes in fermented foods produce factors that control the growth of potential invaders

140 (Steinkraus, 1997) and thus help to stabilize the microbial population within the system.

141 Researchers have found that kombucha does indeed have antimicrobial properties, including

142 activity against many human pathogens (Greenwalt, Ledford \& Steinkraus, 1998; Sreeramulu,

143 Zhu \& Knol, 2000). These features of kombucha make it a tractable model of interspecies

144 dynamics that has implications for food preservation and for human health.

145

146 In this review, we provide a general overview of the cooperative and competitive interactions

147 that occur during kombucha fermentation. For example, yeast produce the invertase enzyme

148 which acts as a public good, breaking down sucrose that can then be used by both yeast and

149 bacteria. The bacteria produce cellulose that becomes the pellicle, which may also act as a public

150 good, protecting the liquid culture from colonization by competitors, delaying desiccation, and

151 possibly acting as a resource store. All of these features of kombucha make it a promising model

152 system for studying multispecies cooperation. Some of these characteristics point to other

153 potential human uses for kombucha and kombucha-derived products, which we discuss at the

154 end of the paper.

155

156 The social biochemistry of kombucha

157 Kombucha brewing begins with a solution of 'sweet tea' (typically 5\%-10\% (w/v) sucrose

158 dissolved in brewed tea) and a small amount of kombucha starter culture (typically 10\%-20\%

159 liquid (v/v) and 2.5\% biofilm (w/v)) from a previously fermented batch (Jayabalan et al., 2014). 
160 The teas used as substrates for kombucha are variable. Black and green teas are most commonly

161 used, but are far from the only substrates tested (Jayabalan et al., 2014; Villarreal-Soto et al.,

162 2018). Other substrates include oolong, jasmine, and mulberry teas (Talawat et al., 2006),

163 rooibos (Gaggia et al., 2019), coconut water (Watawana et al., 2016), and teas produced from

164 various medicinal herbs (Battikh, Bakhrouf \& Ammar, 2012; Velićanski, Cvetković \& Markov, 165 2013).

166

167 Regardless of the initial substrate composition, the starter culture itself provides the main

168 microbial inoculum into the solution. However, airborne or other environmental microbes may

169 interact with or become part of the solution and potentially contribute to the microbial

170 community. While the microbes ferment the substrate, enzymes produced by the yeast cleave

171 sucrose into glucose and fructose and convert these monomers into ethanol and carbon dioxide.

172 Next, bacterial enzymes oxidize ethanol, generating acetic acid that results in an acidic

173 environment. The bacteria also produce cellulose which leads to biofilm formation (Jayabalan et

174 al., 2014; Chakravorty et al., 2016) (see Fig. 1). Below we provide details about these metabolic

175 processes and the microbial social interactions that occur over the course of kombucha

176 fermentation (see Table 1).

177

178 At the beginning of the kombucha fermentation process, yeast produce invertase which cleaves

179 the disaccharide sucrose to its monosaccharide components, glucose and fructose. This phase

180 appears to be the first opportunity for resource interaction between the microorganisms, as the

181 freely liberated monomers are accessible to any microbe as a carbon source. Approximately $99 \%$

182 of the monosaccharides generated by Saccharomyces sp. invertase diffuse into the environment 
183 before the producing yeast can import them (Gore, Youk \& Van Oudenaarden, 2009). Thus,

184 neighboring cells receive the vast majority of the monomers produced by invertase secreted by a

185 focal cell, suggesting that the production of invertase (and the resultant products) fits the classic

186 definition of a non-excludable public good.

187

188 While the invertase produced by yeast appears to be a cooperative good, some yeast do not 189 actually produce it (so called 'cheaters'). Interestingly, a study with Saccharomyces cerevisiae 190 has shown that yeast phenotypes that produce invertase are found in higher frequency than non191 producer phenotypes when in the presence of Escherichia coli (Celiker \& Gore, 2012). In other 192 words, when yeast are grown in co-culture with bacteria, cooperative invertase-producing yeast 193 outperform cheaters that do not produce invertase. Celiker \& Gore (2012) suggest that the rapid 194 depletion of resources by bacteria leads to a scarcity of sugar in the environment, which in turn 195 increases the frequency of the invertase-producing strain (since they are able to capture about 1\% 196 of the sugars they produce, while non-invertase-producers are completely starved). Interestingly, 197 during kombucha brewing, bacteria rapidly transform many of these sugars into the cellulose 198 pellicle (see section below on resource storage). Thus it may be the case that bacteria - by 199 removing sugars from the solution and putting them into the pellicle - change the selective 200 pressures within the kombucha solution so as to favor invertase-producing strains of yeast. 201

202 After the yeast cleave sucrose into its component monomers using invertase, the yeast begin 203 consuming these sugars and producing ethanol. Ethanol can be harmful to both yeast and 204 bacteria, primarily via modifications to cellular membrane structure, function, and integrity (for a 205 review on microbial tolerance to alcohols, see Liu \& Qureshi, 2009). High levels of alcohol can 
206 threaten the viability of the microbes within kombucha. Potentially harmful levels of ethanol are

207 reduced by bacteria that oxidize it and excrete acetic acid, thereby lowering the overall $\mathrm{pH}$ of the

208 fermenting kombucha. These acetic acid bacteria (AAB) that are part of the kombucha are

209 obligate aerobes, meaning that they need access to oxygen to ferment (Saichana et al., 2015). In

210 static conditions, production of the surface biofilm may increase access to oxygen for the

211 microbes that are found within it, including yeast that are embedded in the cellulosic matrix. This

212 may be another example of cooperation between yeast and bacteria that occurs during

213 fermentation of the kombucha.

214

215 Some strains of Dekkera / Brettanomyces can also produce acetic acid in the presence of oxygen

216 (Ciani \& Ferraro, 1997); however, it is yet unclear what proportion of final acid is contributed by

217 the yeast within kombucha. The dominant organic acids within the community are acetic acid,

218 gluconic acid, and glucuronic acid (Jayabalan et al., 2014; De Filippis et al., 2018; Gaggia et al.,

219 2019), but additional acids have been detected and quantified; these include lactic acid

220 (Jayabalan, Marimuthu \& Swaminathan, 2007; Malbasa, Loncar \& M. Djuric, 2008), citric acid

221 (Jayabalan, Marimuthu \& Swaminathan, 2007), malic acid, tartaric acid (Srihari \&

222 Satyanarayana, 2012) and a host of others (see Jayabalan et al. (2014) for a comprehensive list).

223

224 The variety and abundance of acids produced in kombucha raises the question: is the acid

225 produced simply a waste product or does it provide some benefit for the microbes that produce

226 it? In general, low $\mathrm{pH}$ in the solution can select for microbes that are tolerant to acid, while

227 potential competitors and invaders are excluded or inhibited. Acid tolerant yeast in kombucha

228 (such as Dekkera / Brettanomyces) are able to survive and even thrive within acidic conditions 
229 (Blomqvist, 2011; Steensels et al., 2015) that are deleterious to other yeast genera. Similarly, 230 acetic acid bacteria that are present in kombucha (such as Komagataeibacter) are highly acid231 tolerant, while other bacteria are far less tolerant and cannot survive in high acid conditions 232 (Trček, Mira \& Jarboe, 2015). The ability of the kombucha community to generate and tolerate 233 these acidic conditions may provide an overall benefit in terms of protecting the system from 234 invasion by competitor microbes. Indeed, kombucha has been found to be able to inhibit 235 pathogens in vitro and part of this effect (though not all of it) has been ascribed to its acidic character (Greenwalt, Ledford \& Steinkraus, 1998; Sreeramulu, Zhu \& Knol, 2000).

The bacteria-produced biofilm might provide protection from invasion and allow resource storage

240 The most conspicuous facet of the kombucha symbiosis is the SCOBY (though the microbial 241 community exists in the liquid culture as well as in the cellulosic biofilm). The biofilm initially

242 forms a thin layer on the top of the liquid, as small bacteria-produced cellulose filaments rise to 243 the top of the solution and aggregate together. The biofilm becomes larger and stronger with 244 subsequent fermentations, often forming multiple pancake-like layers that are connected with 245 filaments. Komagataeibacter xylinus, regarded as a model species for bacterial cellulose (BC) 246 production (Ross, Mayer \& Benziman, 1991), has been characterized as a core contributor to the 247 cellulose production in some kombucha cultures (Reva et al. 2015; De Filippis et al. 2018) and 248 has been previously described as the dominant species in regards to $\mathrm{BC}$ production in kombucha 249 (Marsh et al 2014). However, recent studies have illustrated an even wider diversity of 250 Komagataeibacter spp. in kombucha than previously known. Interestingly, De Filippis et al.

251 (2018) found that K. xylinus dominates during fermentation in green or black tea at $20^{\circ} \mathrm{C}$, while 
$252 K$. saccharivorans has a growth advantage at $30^{\circ} \mathrm{C}$. As previously mentioned, other members of

253 this genus have also been identified in kombucha - these include $K$. intermedius and $K$. rhaeticus

254 which were found to be abundant in green and black teas at $27^{\circ} \mathrm{C}$, while Gluconobacter entanii

255 was identified nearly exclusively in kombucha fermented with rooibos teas (Gaggia et al. 2019).

256 From these studies, it is clear that the environment has an impact on the composition of

257 community members; there is no apparent 'canonical' species composition across all substrates

258 and all culture conditions.

259

260 Accordingly, species of Acetobacter (Sievers et al., 1995; Chen \& Liu, 2000; Dutta \& Gachhui, 261 2006; Zhang, Zhang \& Xin, 2011), Gluconacetobacter spp. (Yang et al., 2008; Trovatti et al., 262 2011) and Lactobacillus spp. (Wu, Gai \& Ji, 2004; Zhang, Zhang \& Xin, 2011) have also been

263 found in kombucha cultures. For aerobic species that produce BC, such as K. xylinus, agitated

264 bioreactors increase cell growth and cellulose yield by improving the oxygen transfer rate

265 (Reiniati, Hrymak \& Margaritis, 2017); however, rather than forming a surface pellicle, agitation

266 produces spherical or asterisk-like particles of cellulose in the culture media (Bi et al., 2014;

267 Singhsa, Narain \& Manuspiya, 2018). The optimal dissolved oxygen concentration for BC yield

268 for a strain of this bacteria was reported to be $10 \%$ in fed-batch cultures (Hwang et al., 1999), as

269 greater oxygen concentrations result in a shift towards gluconic acid production and reduced cell

270 viability, while lower concentrations reduce cell growth (Lee et al., 2014). Additionally, a variety

271 of carbon sources have been tested and shown to influence the production of BC, with glucose,

272 sucrose, fructose, mannitol, molasses, and various other organic wastes or extracts serving as

273 substrates (for comprehensive reviews on species, strains, carbon sources, culture times, and

274 cellulose yields, see Chawla et al., 2009; Shah et al., 2013; and Jozala et al., 2016). While 
275 glucose is the ideal biosynthetic building block for cellulose production (Jozala et al., 2016), $K$.

276 xylinus can convert it into gluconic acid via glucose dehydrogenase, which has a detrimental

277 effect on cellulose production (Kuo et al., 2016). Interestingly, the addition of $1 \%(\mathrm{v} / \mathrm{v})$ ethanol

278 to a culture medium containing Gluconacetobacter hansenii inhibited cell growth - but resulted

279 in an increase of BC production and a decline of non-cellulose producing mutants (Park, Jung \&

280 Park, 2003). It is unclear whether the yeast-produced ethanol in kombucha communities could

281 perform a similar role with the bacterial partners, but this suggests an avenue for further

282 exploration.

283

284 While the majority of focus has understandably been concentrated on the bacteria-produced 285 biofilm, yeast are known to produce biofilms as well, particularly when a part of mixed species 286 assemblages (Kawarai et al., 2007; Furukawa et al., 2010; León-Romero et al., 2016). It is 287 entirely possible that yeast are contributing to the biofilm structure in kombucha as well.

288 Dekkera / Brettanomyces have been shown to produce biofilms with surface adherence 289 properties directly affected by $\mathrm{pH}$ and sugar concentrations (Joseph et al., 2007). These yeasts 290 could also produce biofilms at different rates based on ploidy status (Ishchuk et al., 2016). These 291 factors could account for some of the non-uniformity observed in the biofilms which grow as 292 multiple layers with strands suspended down (see Fig. 2).

293

294 In addition to the physical thickness of the biofilm, the extracellular polymeric substances (EPS) 295 of the matrix can inhibit the diffusion of antibiotics or invading cells (Stewart, 1996; Mah \& 296 O'Toole, 2001). The presence of this pellicle likely makes it more difficult for microbes landing 297 on the surface to access free sugars that are within the kombucha solution. Williams \& Cannon 
298 (1989) performed a battery of experiments to study the environmental role of the pellicle, 299 including: using in vitro UV irradiation to show that the pellicle decreases the bacteria's 300 susceptibility to UV rays compared to non-pellicle controls, using apple slices as a substrate to 301 show that the pellicle works to retain moisture in the environment, and that pellicle-forming 302 bacteria strains are able to outgrow other, unspecified wild strains of bacteria and molds.

303 Additional experimental work is needed to investigate whether the pellicle provides this 304 protective function in kombucha.

305

306 Another possible benefit that the biofilm may provide is the storage of resources (Jefferson, 307 2004). The biofilm is made of EPS (produced by microbes) which acts as a reservoir of carbon 308 (Flemming \& Wingender, 2010). It can also include polysaccharides like levan which may 309 function as a storage molecule (Limoli, Jones \& Wozniak, 2015), as supported by studies on 310 Pseudomonas syringae (Laue et al., 2006). This might allow it to function as a resource storage 311 system that can only be accessed by the kombucha-associated bacteria and yeast inside the 312 solution if/when sugars become unavailable (e.g., if the system is not being fed fresh, sugar-rich 313 tea). However, further research is necessary to determine whether the pellicle is systematically 314 broken down and used as a resource source during 'starvation' of the kombucha. In addition 315 and related to this hypothesis - it could be that the removal of sugars from the solution by the 316 bacteria creates an environment that favors cooperative invertase-producing yeast over cheater 317 strains (see the section above on invertase; Celiker \& Gore, 2012). In this way, the biofilm 318 provides a resource storage function and also may modify the selective pressures on yeast, 319 favoring cooperation. If the biofilm does indeed change the evolutionary dynamics within the 320 system in ways that inhibit cheaters, this would be an intriguing parallel with certain processes 
321 that happen in multicellular bodies that encourage multicellular cooperation and inhibit cellular

322 cheating (Aktipis et al., 2015).

323

324 Kombucha as a model system for studying cooperation

325 Kombucha is characterized by many different social processes including public good production 326 and cooperation to exclude competitors. This makes it a useful model system for understanding the evolution of cooperation, both in general terms and more specifically in the context of 328 cooperation in multispecies microbial systems. Some ostensibly mutually-beneficial relationships may instead have evolved as indirect exploitation of each partner's waste products or represent by-products of otherwise selfish traits (West, Griffin \& Gardner, 2007). There is also debate about whether strategies that permit the evolution of cooperation in social groups, such as cheater detection and cheater punishment, occur in microbial communities (Travisano \& Velicer, 2004). Kombucha may be a good model system to test for cheater control systems in microbes and also to investigate the evolution of microbial traits that benefit other microbes.

Also, there is important work to be done to understand how multi-species cooperative systems evolve. Kombucha may be a tractable system in which to study this process. Theoretical models suggest that when cooperators get the benefits of interacting with one another (through a process called behavioral assortment), cooperation becomes more viable, regardless of whether individuals are related or even the same species (Fletcher \& Doebeli, 2009). Behavioral assortment occurs when cooperators have more interactions with one another than with noncooperators - and it is a general principle that can select for the evolution of altruism in diverse

343 systems (Fletcher \& Doebeli, 2009). Behavioral assortment is also at the heart of why strategies 
344 like 'Walking Away' from non-cooperators selects for cooperation in both partnerships (Aktipis,

345 2004) and groups (Aktipis, 2011). Kombucha could provide a model system in which to

346 experimentally test these models and uncover the mechanisms that influence the evolution of

347 cooperation in multi-species systems.

348

349 A substantial body of work has focused on social interactions within biofilms, which run the

350 gamut from cooperative to competitive (for a review, see Nadell, Drescher \& Foster, 2016). As

351 the vast majority of biological systems in the natural world exist as multi-species communities, it

352 is important for biofilm researchers to use models that reflect this reality (Tan et al., 2016). The

353 kombucha SCOBY offers an easily-reproducible platform to explore questions about synergy

354 and antagonism in multispecies interactions. While advances in various 'omics' technologies

355 have allowed greater interrogation of such biofilms (Tan et al., 2016; Burmølle et al., 2014),

356 technical challenges remain; these include tracking and maintaining various community

357 members in mixed assemblages (Elias \& Banin, 2012). We argue that the well-characterized

358 organisms often found in the kombucha community could reduce the difficulties in such

359 endeavors. Specifically, the substrates for cell growth are well-established (see previous sections

360 on teas and carbon sources), there are selective media recipes designed to isolate various

361 organisms in acidic or fermented conditions (Beuchat, 1993; Makdesi \& Beuchat, 1996; Sharafi,

362 Rasooli \& Beheshti-Maal, 2010; Morneau, Zuehlke \& Edwards, 2011), and the organisms are

363 already well-adapted to in vitro-like conditions.

364

365 Kombucha also can provide a model system for investigating the evolution of cooperation

366 among hosts and their microbes. There is growing interest in host-microbiome interactions

Peer) reviewing PDF | (2018:09:31579:2:0:NEW 25 Jul 2019) 
367 (Rosenberg \& Zilber-Rosenberg, 2016) and the evolutionary consequences of cooperation and

368 conflict among hosts and their microbes (Alcock, Maley \& Aktipis, 2014; Wasielewski, Alcock

369 \& Aktipis, 2016; Foster et al., 2017). Kombucha might provide a model system for certain

370 aspects of the eukaryote-bacteria interactions that occur between hosts and their microbiomes.

371 Both kombucha and host-microbiome interactions involve a close association between bacterial

372 and eukaryotic cells. In kombucha, eukaryotes are represented by yeast genera, which can

373 include Zygosaccharomyces, Candida, Torulaspora, Pichia, Brettanomyces/Dekkera,

374 Schizosaccharomyces, and Saccharomyces (Mayser et al., 1995; Teoh, Heard \& Cox, 2004;

375 Marsh et al., 2014; Jayabalan et al., 2014; Reva et al., 2015). There is a long history of using

376 yeast as a model system for human disease and health (Botstein, Chervitz \& Cherry, 1997),

377 which suggests that it may be viable to use kombucha as a model system for human health issues 378 that involve interactions of the host eukaryotic cells with bacteria.

379

380 Fermented foods are diverse microbial ecosystems

381 Kombucha is not the only fermented food that is a potentially useful model system for studying

382 multispecies cooperation. Cheese rinds are diverse biofilms formed by bacteria and fungi

383 communities which are influenced by the various processing and aging steps associated with

384 cheese production (Wolfe et al., 2014). Despite the collection of samples across 10 countries and

385137 cheese types, Wolfe et al. (2014) show that these communities were dominated by 14

386 bacterial and 10 fungal genera and demonstrate highly reproducible successional dynamics

387 across vast geographic distances (Wolfe et al., 2014). The adoption of cheese as a model system

388 has produced numerous intriguing findings, such as widespread horizontal gene transfer in rind-

389 associated bacteria (Bonham, Wolfe \& Dutton, 2017) and fungi (Ropars et al., 2015), 
390 characterization of a suite of 'domestication' genes in a common industrial milk fermenting

391 bacterium (Passerini et al., 2010), the rapid experimental evolution of 'domesticated' Penicillium

392 mutants during serial propagation on in vitro cheese agar (Bodinaku et al., 2019), and the

393 application of lactococcal-produced bacteriocins to influence the populations of starter bacteria

394 and pathogenic contaminants (Guinane et al., 2005).

395

396 Another fermented food that has been established as a useful model system is sourdough. The

397 production of sourdough involves an association between lactic acid bacteria and yeast using

398 flour (typically wheat or rye) as a carbon and energy source (Gobbetti, 1998). Mature sourdough

399 is the end product of a series of acidifying fermentation steps initiated by a diverse assemblage of

400 lactic acid bacteria (both facultative and obligate heterofermentative as well as

401 homofermentative species), aerobic gram-positive and gram-negative bacteria,

402 Enterobacteriaceae, yeasts, and molds - that eventually results in the dominance of a few

403 obligate heterofermentative species of Lactobaccillus (sometimes Leuconostoc) and yeast

404 (Minervini et al. 2014). Commonly isolated species of Lactobacillius bacteria include

405 Lactobacilli sanfranciscensis, L. fermentum, L. plantarum, L. brevis, L. rossiae, and other

406 members of the same genus (see Huys et al., 2013 and Minervini et al., 2014), while yeast

407 species are more diverse and commonly include Saccharomyces cerevisiae, Candida humilis,

408 Kazachstania exigua, Pichia kudriavzevii, Wickerhamomyces anomalus, and Torulaspora

409 delbrueckii (De Vuyst et al. 2016). The bacteria preferentially hydrolyze maltose and liberate

410 glucose into the medium, allowing its use by neighboring microbes (particularly maltose-

411 negative species of yeast) and stabilizing the cooperative interaction (De Vuyst \& Neysens,

412 2005). Much like kombucha, the nature and quality of the substrate (flour for sourdough) and the 
413 fermenting conditions have a direct impact on the final community structure that develops,

414 though the various methods used to sample, isolate, and identify the microbes preclude a

415 conclusive link between a sourdough and its microbial consortia (De Vuyst et al., 2014). All of

416 this variation affects the genera and species involved at various stages of fermentation, which in

417 turn affects the final product (De Vuyst \& Neysens, 2005).

418

419 Kefir may also be a useful fermented food for studying multispecies cooperation. It is a

420 fermented milk beverage propagated by a starter 'grain' composed of a complex but stable

421 community of lactic acid bacteria, acetic acid bacteria, and yeast (Simova et al., 2002). As in

422 kombucha and sourdough, the yeast component of the kefir community varies, with

423 Saccharomyces and Candida as the genera most frequently identified, but it is also known to

424 contain Kluyveromyces (Farnworth, 2006). The kefir system appears to be characterized by

425 cooperation as well since yeast provide the bacteria with growth-promoting compounds (amino

426 acids, vitamins) during the early stages of fermentation, and the resulting bacterial products can

427 be exploited as a source of energy for the yeast (Loretan et al., 1998; Viljoen, 2001). These are

428 just some of the fermented foods that allow opportunities for examining cooperation and

429 competition in microbial communities - more generally, they may provide useful and tractable

430 experimental systems for studying these social and evolutionary dynamics.

431

432 Kombucha and other fermented foods may provide benefits to

433 humans

434 Fermented foods have many potential benefits to humans and so understanding the dynamics of

435 cooperation and conflict among microbes in systems like kombucha can have important 
436 applications as well. In developing countries they already provide an important source of protein 437 and vitamins (Steinkraus, 1997). The microbes in fermented foods also help protect the food 438 from microorganisms that might otherwise spoil it - maintaining the nutritional quality of the 439 food and helping to keep it safe for human consumption for long periods of time (Steinkraus, 440 1997). It is possible that kombucha may provide similar benefits. In addition, due to the ability of 441 kombucha to inhibit pathogen growth via acidity (Greenwalt, Ledford \& Steinkraus, 1998) and 442 other mechanisms (Sreeramulu, Zhu \& Knol, 2000, Bhattacharya et al., 2016, Shahbazi et., 443 2018), kombucha and its constituents are excellent candidates for developing novel agents to 444 control pathogens and food-spoilage microbes. This is a possibility we are currently exploring in 445 our laboratory.

447 It is not yet known how kombucha influences human health, although tea polyphenols have been 448 shown elsewhere to confer health benefits (Dufresne \& Farnworth, 2000) including potentially 449 decreasing cancer risk (Beltz et al., 2006). During kombucha fermentation, it was shown that the 450 concentration of polyphenols first decreases and then spikes at day 12, leading to higher levels of 451 polyphenols than were originally in the solution, possibly due to the release of additional 452 catechins or enzymes by cell lysis (Jayabalan, Marimuthu \& Swaminathan, 2007). However, 453 work by Gaggia et al. (2019) has shown that polyphenol content increases at first and then 454 decreases over further fermentation time. The type of tea and microbial population (and their 455 interactions with each other) seem to directly influence the level of polyphenols. It is possible 456 that these compounds in kombucha may have some positive effect on health, but more studies 457 are needed to identify these potential influences on health and the mechanisms underlying them. 458 
459 Cellulose biofilms produced by acetic acid bacteria - like the SCOBY in kombucha - have been 460 developed into useful materials for medical and textile purposes. For example, cellulose biofilms 461 have been developed for medical dressings (Lin et al., 2013), skin tissue repair (Fu, Zhang \& 462 Yang, 2013), incorporation into composite materials (Shah et al., 2013), and even clothing (Lee 463 \& Ghalachyan, 2015). These examples suggest that biofilms produced by kombucha 464 fermentation can be used in a variety of beneficial products.

465

\section{The role of viruses in fermented foods is currently unknown}

467 An additional potential player in the cooperative and competitive dynamics inside kombucha and 468 other fermented foods is viruses. The role of viruses in fermented foods has been largely 469 unstudied due to challenges related to culturing, but recent advances have been made with the 470 widespread adoption of metagenomic technologies (Park et al., 2011). Analysis of kimchi, 471 sauerkraut, and fermented shrimp indicate that these foods contain less complex viral 472 communities than environmental samples, possibly due to their limited microbial hosts (Park et 473 al., 2011). Jung et al. (2011) found evidence that the phage burden of the dominant bacteria 474 during the late stages of kimchi fermentation has a direct impact on bacterial abundance and 475 accordingly affected the resulting community dynamics. In sauerkraut, the succession of host 476 bacteria - and their subsequent effects on fermentation - may be directly influenced by the 477 activity of their associated phages (Lu, Breidt \& Plengvidhya, 2003). Phages have not yet been 478 studied in kombucha fermentation. But, given their presence in other fermented foods, it is likely 479 that they play a role in kombucha. 
481 Not all viruses are harmful - in fact, a growing body of research shows that many viruses may

482 sometimes benefit their hosts (Roossinck, 2011, 2015). An intriguing topic for future study is the

483 possibility that phages and other viruses maintain conditions that permit multispecies

484 cooperation in kombucha and other fermented foods. Viruses have been shown to slow down

485 microbial cell cycles (Nascimento, Costa \& Parkhouse, 2012) and alter metabolism and the

486 composition of metabolites that are produced (Sanchez \& Lagunoff, 2015). These features may

487 potentially stabilize microbial ecosystems during food fermentation, perhaps inhibiting the

488 proliferation of some microbes while allowing others. Some viruses also have the capacity to

489 restore intestinal morphology and mucosal immunity of germfree or antibiotic-treated mice

490 without causing disease (Kernbauer, Ding \& Cadwell, 2014), suggesting that they may also have

491 a positive effect on host epithelial cells during digestion. It is possible that viruses contribute to

492 the stability and viability of the ecological systems of fermented foods and the fermentation

493 processes in the gut microbiome. To the extent that viruses stabilize microbial communities, their

494 role in maintaining a microbial ecosystem favorable for viral growth may provide an

495 evolutionarily beneficial strategy for those viral strains. The role of viruses in multispecies

496 cooperative interactions has been underexplored and is worthy of future research.

497

498 Conclusions

499 Kombucha is a fermented tea that is brewed by combining sweet tea with a small amount of

500 kombucha starter which contains both yeast and bacteria. Over the course of fermentation, the

501 yeast and bacteria cooperate in many ways - some of which are known and some which require

502 further characterization - to metabolize resources and keep out invading microbes. Kombucha

503 offers a unique opportunity for exploring general questions about the evolution of cooperation 
504 and also for exploring more specific questions about cooperation in complex multispecies

505 systems. The social lives of the microbes within the community - particularly how they exchange

506 resources, signal potential partners, or even deter so-called 'free-riders' - are exciting directions

507 for future work. There are also many potential applications of kombucha for human nutrition,

508 material development, and even for controlling the growth of harmful microbes.

509

510 Acknowledgements

511 The authors wish to thank the Microbiome and Behavior Project members and the Cooperation

512 and Conflict lab for discussion and insights during the development of this article.

513

514 References

515 Aktipis CA. 2004. Know when to walk away: contingent movement and the evolution of

516 cooperation. Journal Of Theoretical Biology 231:249-260. DOI: 10.1016/j.jtbi.2004.06.020.

517

518 Aktipis CA. 2011. Is cooperation viable in mobile organisms? Simple Walk Away rule

519 favors the evolution of cooperation in groups. Evolution And Human Behavior: Official

520 Journal Of The Human Behavior And Evolution Society 32:263-276. DOI:

$521 \quad$ 10.1016/j.evolhumbehav.2011.01.002.

522

523

524

Aktipis CA, Boddy AM, Jansen G, Hibner U, Hochberg ME, Maley CC, Wilkinson GS. 2015. Cancer across the tree of life: cooperation and cheating in multicellularity.

525 Philosophical Transactions Of The Royal Society Of London. Series B, Biological Sciences 370. DOI: $10.1098 /$ rstb.2014.0219. 
527

528 Alcock J, Maley CC, Aktipis CA. 2014. Is eating behavior manipulated by the

529 gastrointestinal microbiota? Evolutionary pressures and potential mechanisms. Bioessays:

530 News And Reviews In Molecular, Cellular And Developmental Biology 36:940-949. DOI:

$531 \quad 10.1002 /$ bies.201400071.

532

533 Ann Beltz L, Kay Bayer D, Lynn Moss A, Mitchell Simet I. 2006. Mechanisms of Cancer

534 Prevention by Green and Black Tea Polyphenols. Anti-Cancer Agents in Medicinal

535 Chemistry-Anti-Cancer Agents) 6:389-406. DOI: 10.2174/187152006778226468.

536

537 Battikh H, Bakhrouf A, Ammar E. 2012. Antimicrobial effect of Kombucha analogues. $L W T$

538 - Food Science And Technology 47:71-77. DOI: 10.1016/j.1wt.2011.12.033.

539

540 Beuchat LR. 1993. Selective media for detecting and enumerating foodborne

541 yeasts. International Journal Of Food Microbiology 19:1-14.

542

543 Bhattacharya D, Bhattacharya S, Patra MM, Chakravorty S, Sarkar S, Chakraborty W, Koley

544 H, Gachhui R. 2016. Antibacterial Activity of Polyphenolic Fraction of Kombucha Against

545 Enteric Bacterial Pathogens. Current Microbiology 73:885-896. DOI: 10.1007/s00284-016-

$546 \quad 1136-3$.

547

548 Bi J-C, Liu S-X, Li C-F, Li J, Liu L-X, Deng J, Yang Y-C. 2014. Morphology and structure 549 characterization of bacterial celluloses produced by different strains in agitated culture. 
550 Journal Of Applied Microbiology 117:1305-1311. DOI: 10.1111/jam.12619.

551

552 Blomqvist J. 2011. Dekkera bruxellensis - a competitive yeast for ethanol production from

553 conventional and non-conventional substrates. Doctoral Thesis, Swedish University of

554 Agricultural Sciences. Retrieved from https://pub.epsilon.slu.se/8404/

555

556 Bodinaku I, Shaffer J, Connors AB, Steenwyk JL, Kastman E, Rokas A, Robbat A, Wolfe B.

557 2019. Rapid phenotypic and metabolomic domestication of wild Penicillium molds on

558 cheese. bioRxiv: 647172. DOI: 10.1101/647172.

559

560 Bonham KS, Wolfe BE, Dutton RJ. 2017. Extensive horizontal gene transfer in cheese-

561 associated bacteria. eLife 6. DOI: 10.7554/eLife.22144.

562

563 Botstein D, Chervitz SA, Cherry JM. 1997. Yeast as a model organism. Science 277:1259$564 \quad 1260$.

565

566

Burmølle M, Ren D, Bjarnsholt T, Sørensen SJ. 2014. Interactions in multispecies biofilms:

567 do they actually matter? Trends In Microbiology 22:84-91. DOI: 10.1016/j.tim.2013.12.004.

568

569 Celiker H, Gore J. 2012. Competition between species can stabilize public-goods cooperation 570 within a species. Molecular Systems Biology.

571

572 Chakravorty S, Bhattacharya S, Chatzinotas A, Chakraborty W, Bhattacharya D, Gachhui R. 
573 2016. Kombucha tea fermentation: Microbial and biochemical dynamics. International

574 Journal Of Food Microbiology 220:63-72. DOI: 10.1016/j.jifoodmicro.2015.12.015.

575

576 Chawla PR, Bajaj IB, Survase SA, Singhal RS. 2009. Microbial cellulose: fermentative 577 production and applications. Food Technology And Biotechnology 47.

578

579 Chen C, Liu BY. 2000. Changes in major components of tea fungus metabolites during 580 prolonged fermentation. Journal Of Applied Microbiology 89:834-839.

581

582 Ciani M, Ferraro L. 1997. Role of oxygen on acetic acid production by

583 Brettanomyces/Dekkera in winemaking. Journal Of The Science Of Food And Agriculture

584 75:489-495. DOI: 10.1002/(SICI)1097-0010(199712)75:4<489::AID-JSFA902>3.0.CO;2-9.

585

586 De Filippis F, Troise AD, Vitaglione P, Ercolini D. 2018. Different temperatures select

587 distinctive acetic acid bacteria species and promotes organic acids production during

588 Kombucha tea fermentation. Food Microbiology 73:11-16. DOI: 10.1016/j.fm.2018.01.008.

589

590 De Vuyst L, Harth H, Van Kerrebroeck S, Leroy F. 2016. Yeast diversity of sourdoughs and 591 associated metabolic properties and functionalities. International Journal Of Food

592 Microbiology 239:26-34. DOI: 10.1016/j.ijfoodmicro.2016.07.018.

593

594 De Vuyst L, Neysens P. 2005. The sourdough microflora: biodiversity and metabolic 595 interactions. Trends in Food Science \& Technology 16:43-56. DOI: 
$596 \quad$ 10.1016/j.tifs.2004.02.012.

597

598 De Vuyst L, Van Kerrebroeck S, Harth H, Huys G, Daniel H-M, Weckx S. 2014. Microbial 599 ecology of sourdough fermentations: diverse or uniform? Food Microbiology 37:11-29.

$600 \quad$ DOI: $10.1016 /$ j.fm.2013.06.002.

601

602 Dos Santos RAC, Berretta AA, Barud H da S, Ribeiro SJL, González-García LN, Zucchi TD, 603 Goldman GH, Riaño-Pachón DM. 2015. Draft Genome Sequence of Komagataeibacter 604 intermedius Strain AF2, a Producer of Cellulose, Isolated from Kombucha Tea. Genome 605 Announcements 3. DOI: 10.1128/genomeA.01404-15.

606

607 Dufresne C, Farnworth E. 2000. Tea, Kombucha, and health: a review. Food Research 608 International 33:409-421.

609

610 Dutta D, Gachhui R. 2006. Novel nitrogen-fixing Acetobacter nitrogenifigens sp. nov., 611 isolated from Kombucha tea. International Journal Of Systematic And Evolutionary 612 Microbiology 56:1899-1903. DOI: 10.1099/ijs.0.64101-0.

613

614 Elias S, Banin E. 2012. Multi-species biofilms: living with friendly neighbors. FEMS 615 Microbiology Reviews 36:990-1004. DOI: 10.1111/j.1574-6976.2012.00325.x.

616

617 Farnworth ER. 2006. Kefir--a complex probiotic. Food Science and Technology Bulletin: $618 \quad$ Functional Foods 2:1-17. 
619

620 Flemming H-C, Wingender J. 2010. The biofilm matrix. Nature Reviews. Microbiology

621 8:623-633. DOI: 10.1038/nrmicro2415.

622

623 Fletcher JA, Doebeli M. 2009. A simple and general explanation for the evolution of 624 altruism. Proceedings. Biological Sciences / The Royal Society 276:13-19. DOI:

$625 \quad 10.1098 /$ rspb.2008.0829.

626

627 Foster KR, Schluter J, Coyte KZ, Rakoff-Nahoum S. 2017. The evolution of the host 628 microbiome as an ecosystem on a leash. Nature 548:43-51. DOI: 10.1038/nature23292.

629

630 Franzosa EA, Hsu T, Sirota-Madi A, Shafquat A, Abu-Ali G, Morgan XC, Huttenhower C.

631 2015. Sequencing and beyond: integrating molecular "omics" for microbial community

632 profiling. Nature Reviews. Microbiology 13:360-372. DOI: 10.1038/nrmicro3451.

633

634 Fu L, Zhang J, Yang G. 2013. Present status and applications of bacterial cellulose-based 635 materials for skin tissue repair. Carbohydrate Polymers 92:1432-1442. DOI:

$636 \quad 10.1016 /$ j.carbpol.2012.10.071.

637

638 Furukawa S, Yoshida K, Ogihara H, Yamasaki M, Morinaga Y. 2010. Mixed-species biofilm 639 formation by direct cell-cell contact between brewing yeasts and lactic acid bacteria.

640 Bioscience, Biotechnology, And Biochemistry 74:2316-2319. DOI: 10.1271/bbb.100350. 
642 Gaggìa F, Baffoni L, Galiano M, Nielsen DS, Jakobsen RR, Castro-Mejía JL, Bosi S, Truzzi

643 F, Musumeci F, Dinelli G, Di Gioia D. 2019. Kombucha Beverage from Green, Black and

644 Rooibos Teas: A Comparative Study Looking at Microbiology, Chemistry and Antioxidant

645 Activity. Nutrients 11. DOI: 10.3390/nu11010001.

646

647 Gobbetti M. 1998. The sourdough microflora: Interactions of lactic acid bacteria and yeasts.

648 Trends in Food Science \& Technology 9:267-274. DOI: 10.1016/S0924-2244(98)00053-3.

649

650 Gore J, Youk H, Van Oudenaarden A. 2009. Snowdrift game dynamics and facultative $651 \quad$ cheating in yeast. Nature 459: 253-256.

652

653 Greenwalt CJ, Ledford RA, Steinkraus KH. 1998. Determination and Characterization of the 654 Antimicrobial Activity of the Fermented Tea Kombucha. LWT - Food Science and 655 Technology 31:291-296. DOI: 10.1006/fstl.1997.0354.

656

657 Greig D, Travisano M. 2004. The Prisoner's Dilemma and polymorphism in yeast SUC 658 genes. Proceedings. Biological Sciences / The Royal Society 271 Suppl 3:S25-6. DOI: $659 \quad 10.1098 / \mathrm{rsbl} .2003 .0083$.

660

661 Guinane CM, Cotter PD, Hill C, Ross RP. 2005. Microbial solutions to microbial problems; 662 lactococcal bacteriocins for the control of undesirable biota in food. Journal Of Applied 663 Microbiology 98:1316-1325. DOI: 10.1111/j.1365-2672.2005.02552.x. 
665 Habets MGJL, Rozen DE, Hoekstra RF, de Visser JAGM. 2006. The effect of population 666 structure on the adaptive radiation of microbial populations evolving in spatially structured 667 environments. Ecology Letters 9:1041-1048. DOI: 10.1111/j.1461-0248.2006.00955.x.

668

669 Huys G, Daniel H-M, De Vuyst L. 2013. Taxonomy and Biodiversity of Sourdough Yeasts 670 and Lactic Acid Bacteria. In: Gobbetti M, Gänzle M eds. Handbook on Sourdough

671 Biotechnology. Boston, MA: Springer US, 105-154. DOI: 10.1007/978-1-4614-5425-0_5.

672

673 Hwang JW, Yang YK, Hwang JK, Pyun YR, Kim YS. 1999. Effects of pH and dissolved 674 oxygen on cellulose production by Acetobacter xylinum BRC5 in agitated culture. Journal Of 675 Bioscience And Bioengineering 88:183-188.

676

677 Ishchuk OP, Vojvoda Zeljko T, Schifferdecker AJ, Mebrahtu Wisén S, Hagström ÅK, 678 Rozpędowska E, Rørdam Andersen M, Hellborg L, Ling Z, Sibirny AA, Piškur J. 2016. 679 Novel Centromeric Loci of the Wine and Beer Yeast Dekkera bruxellensis CEN1 and CEN2. $680 \quad$ PloS One 11:e0161741. DOI: 10.1371/journal.pone.0161741.

681

682 Jayabalan R, Malbaša RV, Lončar ES, Vitas JS, Sathishkumar M. 2014. A Review on 683 Kombucha Tea-Microbiology, Composition, Fermentation, Beneficial Effects, Toxicity, 684 and Tea Fungus. Comprehensive Reviews in Food Science and Food Safety 13:538-550.

685 DOI: $10.1111 / 1541-4337.12073$.

686

687 Jayabalan R, Marimuthu S, Swaminathan K. 2007. Changes in content of organic acids and 
688 tea polyphenols during kombucha tea fermentation. Food Chemistry 102:392-398. DOI:

$689 \quad$ 10.1016/j.foodchem.2006.05.032.

690

691 Jefferson KK. 2004. What drives bacteria to produce a biofilm? FEMS Microbiology Letters 692 236:163-173. DOI: 10.1016/j.femsle.2004.06.005.

693

694 Jessup CM, Kassen R, Forde SE, Kerr B, Buckling A, Rainey PB, Bohannan BJM. 2004. Big 695 questions, small worlds: microbial model systems in ecology. Trends In Ecology \& Evolution 696 19:189-197. DOI: 10.1016/j.tree.2004.01.008.

697

698 Joseph CML, Kumar G, Su E, Bisson LF. 2007. Adhesion and biofilm production by wine 699 isolates of Brettanomyces bruxellensis. American Journal Of Enology And Viticulture $700 \quad 58: 373-378$.

701

702 Jozala AF, de Lencastre-Novaes LC, Lopes AM, de Carvalho Santos-Ebinuma V, Mazzola 703 PG, Pessoa A Jr, Grotto D, Gerenutti M, Chaud MV. 2016. Bacterial nanocellulose 704 production and application: a 10-year overview. Applied Microbiology And Biotechnology 705 100:2063-2072. DOI: 10.1007/s00253-015-7243-4.

706

707 Jung JY, Lee SH, Kim JM, Park MS, Bae J-W, Hahn Y, Madsen EL, Jeon CO. 2011.

708 Metagenomic analysis of kimchi, a traditional Korean fermented food. Applied And 709 Environmental Microbiology 77:2264-2274. DOI: 10.1128/AEM.02157-10. 
711 Kawarai T, Furukawa S, Ogihara H, Yamasaki M. 2007. Mixed-species biofilm formation by

712 lactic acid bacteria and rice wine yeasts. Applied And Environmental Microbiology 73:4673-

713 4676. DOI: 10.1128/AEM.02891-06.

\section{4}

715 Kernbauer E, Ding Y, Cadwell K. 2014. An enteric virus can replace the beneficial function 716 of commensal bacteria. Nature 516:94-98. DOI: 10.1038/nature13960.

717

718 Kuo C-H, Chen J-H, Liou B-K, Lee C-K. 2016. Utilization of acetate buffer to improve 719 bacterial cellulose production by Gluconacetobacter xylinus. Food Hydrocolloids 53:98-103. $720 \quad$ DOI: $10.1016 /$ j.foodhyd.2014.12.034.

721

722 Laue H, Schenk A, Li H, Lambertsen L, Neu TR, Molin S, Ullrich MS. 2006. Contribution of 723 alginate and levan production to biofilm formation by Pseudomonas syringae. Microbiology 724 152:2909-2918. DOI: 10.1099/mic.0.28875-0.

725

726 Lee K-Y, Buldum G, Mantalaris A, Bismarck A. 2014. More than meets the eye in bacterial 727 cellulose: biosynthesis, bioprocessing, and applications in advanced fiber composites. 728 Macromolecular Bioscience 14:10-32. DOI: 10.1002/mabi.201300298.

729

730

731

Lee Y-A, Ghalachyan A. 2015. RETHINK: Wearing Kombucha in Santa Fe. International Textile and Apparel Association Annual Conference Proceedings 2015, 95. Available at:

732 https://lib.dr.iastate.edu/itaa_proceedings/2015/design/95 (accessed November 2017). 
734 León-Romero Á, Domínguez-Manzano J, Garrido-Fernández A, Arroyo-López FN, Jiménez-

735 Díaz R. 2016. Formation of In Vitro Mixed-Species Biofilms by Lactobacillus pentosus and

$736 \quad$ Yeasts Isolated from Spanish-Style Green Table Olive Fermentations. Applied and

737 Environmental Microbiology 82:689-695. DOI: 10.1128/AEM.02727-15.

738

739 Limoli DH, Jones CJ, Wozniak DJ. 2015. Bacterial Extracellular Polysaccharides in Biofilm

740 Formation and Function. Microbiology Spectrum 3. DOI: 10.1128/microbiolspec.MB-0011-

7412014.

742

743 Lin W-C, Lien C-C, Yeh H-J, Yu C-M, Hsu S-H. 2013. Bacterial cellulose and bacterial

744 cellulose-chitosan membranes for wound dressing applications. Carbohydrate Polymers

745 94:603-611. DOI: 10.1016/j.carbpol.2013.01.076.

746

747 Liu S, Qureshi N. 2009. How microbes tolerate ethanol and butanol. New Biotechnology

$748 \quad$ 26:117-121. DOI: 10.1016/j.nbt.2009.06.984.

749

750 Loretan T, Mostert JF, Voegel AM, du P. (Animal Nutrition and Animal Products Inst. Irene

751 (South Africa)) JHF, Viljoen BC. 1998. A preliminary study on the diversity and

752 technological properties of indigenous traditional South African fermented milk. In Yeasts in

753 the dairy industry: positive and negative aspects, Copenhagen (Denmark) Symposium, 2-3

754 Sep 1996, International Dairy Federation. 
756 Lu Z, Breidt F, Plengvidhya V. 2003. Bacteriophage ecology in commercial sauerkraut

757 fermentations. Applied and Environmental Microbiology, 69: 3192-3202.

758

759 Machado RTA, Gutierrez J, Tercjak A, Trovatti E, Uahib FGM, Moreno G de P, Nascimento

760 AP, Berreta AA, Ribeiro SJL, Barud HS. 2016. Komagataeibacter rhaeticus as an alternative

761 bacteria for cellulose production. Carbohydrate Polymers 152:841-849. DOI:

$762 \quad$ 10.1016/j.carbpol.2016.06.049.

763

764 MacLean RC. 2008. The tragedy of the commons in microbial populations: insights from 765 theoretical, comparative and experimental studies. Heredity 100:471-477.

766

767 Mah TF, O’Toole GA. 2001. Mechanisms of biofilm resistance to antimicrobial agents.

768 Trends in Microbiology 9:34-39.

769

770 Makdesi AK, Beuchat LR. 1996. Performance of Selective Media for Enumerating

771 Zygosaccharomyces bailii in Acidic Foods and Beverages. Journal of Food Protection 59:

772 652-656. DOI: 10.4315/0362-028X-59.6.652.

773

774 Malbaša R, Lončar E, Djurić M. 2008. Comparison of the products of Kombucha

775 fermentation on sucrose and molasses. Food Chemistry 106:1039-1045. DOI:

$776 \quad$ 10.1016/j.foodchem.2007.07.020. 
777

778 Marsh AJ, O’Sullivan O, Hill C, Ross RP, Cotter PD. 2014. Sequence-based analysis of the

779 bacterial and fungal compositions of multiple kombucha (tea fungus) samples. Food

$780 \quad$ Microbiology 38:171-178. DOI: 10.1016/j.fm.2013.09.003.

781

782 Mayser P, Fromme S, Leitzmann C, Gründer K. 1995. The yeast spectrum of the "tea fungus

783 Kombucha." Mycoses 38:289-295.

784

785 Minervini F, De Angelis M, Di Cagno R, Gobbetti M. 2014. Ecological parameters

786 influencing microbial diversity and stability of traditional sourdough. International Journal

787 Of Food Microbiology 171:136-146. DOI: 10.1016/j.ijfoodmicro.2013.11.021.

788

789

Morneau AD, Zuehlke JM, Edwards CG. 2011. Comparison of media formulations used to

790 selectively cultivate Dekkera/Brettanomyces. Letters in Applied Microbiology 53:460-465.

$791 \quad$ DOI: $10.1111 / \mathrm{j} .1472-765 X .2011 .03133 . x$.

792

793 Nadell CD, Drescher K, Foster KR. 2016. Spatial structure, cooperation and competition in 794 biofilms. Nature Reviews: Microbiology 14:589-600. DOI: 10.1038/nrmicro.2016.84

795

796 Nascimento R, Costa H, Parkhouse RME. 2012. Virus manipulation of cell cycle.

797 Protoplasma 249:519-528. DOI: 10.1007/s00709-011-0327-9.

798 
799 Park JK, Jung JY, Park YH. 2003. Cellulose production by Gluconacetobacter hansenii in a 800 medium containing ethanol. Biotechnology Letters 25:2055-2059. DOI:

$801 \quad$ 10.1023/B:BILE.0000007065.63682.18.

802

803 Park E-J, Kim K-H, Abell GCJ, Kim M-S, Roh SW, Bae J-W. 2011. Metagenomic analysis 804 of the viral communities in fermented foods. Applied and Environmental Microbiology 805 77:1284-1291. DOI: 10.1128/AEM.01859-10.

806

807 Passerini D, Beltramo C, Coddeville M, Quentin Y, Ritzenthaler P, Daveran-Mingot M-L, Le 808 Bourgeois P. 2010. Genes but not genomes reveal bacterial domestication of Lactococcus 809 lactis. PloS One 5:e15306. DOI: 10.1371/journal.pone.0015306.

810

811 Rainey PB, Travisano M. 1998. Adaptive radiation in a heterogeneous environment. Nature 812 394:69-72. DOI: 10.1038/27900.

813

814 Ratcliff WC, Denison RF, Borrello M, Travisano M. 2012. Experimental evolution of 815 multicellularity. Proceedings of the National Academy of Sciences of the United States of 816 America 109:1595-1600. DOI: 10.1073/pnas.1115323109.

817

818 Reiniati I, Hrymak AN, Margaritis A. 2017. Kinetics of cell growth and crystalline 819 nanocellulose production by Komagataeibacter xylinus. Biochemical Engineering Journal 820 127:21-31. DOI: 10.1016/j.bej.2017.07.007. 
822 Reva ON, Zaets IE, Ovcharenko LP, Kukharenko OE, Shpylova SP, Podolich OV, de Vera J-

823 P, Kozyrovska NO. 2015. Metabarcoding of the kombucha microbial community grown in 824 different microenvironments. AMB Express 5:124. DOI: 10.1186/s13568-015-0124-5.

825

826 Roossinck MJ. 2011. The good viruses: viral mutualistic symbioses. Nature Reviews.

827 Microbiology 9:99-108. DOI: 10.1038/nrmicro2491.

828

829 Roossinck MJ. 2015. Move over, bacteria! Viruses make their mark as mutualistic microbial 830 symbionts. Journal of Virology 89:6532-6535. DOI: 10.1128/JVI.02974-14.

831

832 Ropars J, Rodríguez de la Vega RC, López-Villavicencio M, Gouzy J, Sallet E, Dumas É, 833 Lacoste S, Debuchy R, Dupont J, Branca A, Giraud T. 2015. Adaptive Horizontal Gene 834 Transfers between Multiple Cheese-Associated Fungi. Current Biology: CB 25:2562-2569. 835 DOI: $10.1016 /$ j.cub.2015.08.025.

836

837 Rosenberg E, Zilber-Rosenberg I. 2016. Microbes Drive Evolution of Animals and Plants: 838 the Hologenome Concept. mBio 7:e01395. DOI: 10.1128/mBio.01395-15.

839

840 Ross P, Mayer R, Benziman M. 1991. Cellulose biosynthesis and function in bacteria. $841 \quad$ Microbiological Reviews 55:35-58.

842

843 Saichana N, Matsushita K, Adachi O, Frébort I, Frebortova J. 2015. Acetic acid bacteria: A 844 group of bacteria with versatile biotechnological applications. Biotechnology Advances 
845 33:1260-1271. DOI: 10.1016/j.biotechadv.2014.12.001.

846

847 Sanchez EL, Lagunoff M. 2015. Viral activation of cellular metabolism. Virology 479-

848 480:609-618. DOI: 10.1016/j.virol.2015.02.038.

849

850 Semjonovs P, Ruklisha M, Paegle L, Saka M, Treimane R, Skute M, Rozenberga L, Vikele

851 L, Sabovics M, Cleenwerck I. 2017. Cellulose synthesis by Komagataeibacter rhaeticus

852 strain P 1463 isolated from Kombucha. Applied Microbiology and Biotechnology 101:1003-

853 1012. DOI: $10.1007 / \mathrm{s} 00253-016-7761-8$.

854

855 Shah N, Ul-Islam M, Khattak WA, Park JK. 2013. Overview of bacterial cellulose

856 composites: a multipurpose advanced material. Carbohydrate Polymers 98:1585-1598. DOI:

$857 \quad$ 10.1016/j.carbpol.2013.08.018.

858

859 Shahbazi H, Hashemi Gahruie H, Golmakani M-T, Eskandari MH, Movahedi M. 2018.

860 Effect of medicinal plant type and concentration on physicochemical, antioxidant,

861 antimicrobial, and sensorial properties of kombucha. Food Science \& Nutrition 6:2568-2577.

862 DOI: $10.1002 /$ fsn3.873.

863

864 Sharafi S, Rasooli I, Beheshti-Maal K. 2010. Isolation, characterization and optimization of

865 indigenous acetic acid bacteria and evaluation of their preservation methods. Iranian Journal 866 of Microbiology 2:38-45.

867 
868 Sievers M, Lanini C, Weber A, Schuler-Schmid U, Teuber M. 1995. Microbiology and 869 Fermentation Balance in a Kombucha Beverage Obtained from a Tea Fungus Fermentation. 870 Systematic And Applied Microbiology 18:590-594. DOI: 10.1016/S0723-2020(11)80420-0. 871

872 Simova E, Beshkova D, Angelov A, Hristozova T, Frengova G, Spasov Z. 2002. Lactic acid 873 bacteria and yeasts in kefir grains and kefir made from them. Journal Of Industrial 874 Microbiology \& Biotechnology 28:1-6. DOI: 10.1038/sj/jim/7000186.

875

876 Singhsa P, Narain R, Manuspiya H. 2018. Physical structure variations of bacterial cellulose 877 produced by different Komagataeibacter xylinus strains and carbon sources in static and 878 agitated conditions. Cellulose 25:1571-1581. DOI: 10.1007/s10570-018-1699-1. 879

880 Sreeramulu G, Zhu Y, Knol W. 2000. Kombucha fermentation and its antimicrobial activity. $881 \quad$ Journal Of Agricultural And Food Chemistry 48:2589-2594.

882

883 Srihari T, Satyanarayana U. 2012. Changes in free radical scavenging activity of kombucha 884 during fermentation. Research Journal Of Pharmaceutical, Biological And Chemical $885 \quad$ Sciences 4:1978.

886

887 Steensels J, Daenen L, Malcorps P, Derdelinckx G, Verachtert H, Verstrepen KJ. 2015.

888 Brettanomyces yeasts-From spoilage organisms to valuable contributors to industrial 889 fermentations. International Journal Of Food Microbiology 206:24-38. 
891 Steinkraus KH. 1997. Classification of fermented foods: worldwide review of household

892 fermentation techniques. Food Control 8:311-317. DOI: 10.1016/S0956-7135(97)00050-9.

893

894 Stewart PS. 1996. Theoretical aspects of antibiotic diffusion into microbial biofilms.

895 Antimicrobial Agents And Chemotherapy 40:2517-2522.

896

897 Strassmann JE, Zhu Y, Queller DC. 2000. Altruism and social cheating in the social amoeba 898 Dictyostelium discoideum. Nature 408:965-967. DOI: 10.1038/35050087.

899

900 Talawat S, Ahantharik P, Laohawiwattanakul S, Premsuk A, Ratanapo S. 2006. Efficacy of 901 fermented teas in antibacterial activity. Kasetsart Journal of Natural Science 40:925-933.

902

903 Tan CH, Lee KWK, Burmølle M, Kjelleberg S, Rice SA. 2017. All together now:

904 experimental multispecies biofilm model systems. Environmental Microbiology 19:42-53.

905 DOI: $10.1111 / 1462-2920.13594$.

906

907 Teoh AL, Heard G, Cox J. 2004. Yeast ecology of Kombucha fermentation. International

908 Journal Of Food Microbiology 95:119-126. DOI: 10.1016/j.ijfoodmicro.2003.12.020.

909

910 Travisano M, Velicer GJ. 2004. Strategies of microbial cheater control. Trends In

911 Microbiology 12:72-78. DOI: 10.1016/j.tim.2003.12.009.

912

913 Trček J, Mira NP, Jarboe LR. 2015. Adaptation and tolerance of bacteria against acetic acid. 
914 Applied Microbiology And Biotechnology 99:6215-6229. DOI: 10.1007/s00253-015-6762-3.

915

916 Trovatti E, Serafim LS, Freire CSR, Silvestre AJD, Neto CP. 2011. Gluconacetobacter

917 sacchari: An efficient bacterial cellulose cell-factory. Carbohydrate Polymers 86:1417-

918 1420. DOI: 10.1016/j.carbpol.2011.06.046.

919

920 Vartoukian SR, Palmer RM, Wade WG. 2010. Strategies for culture of "unculturable"

$921 \quad$ bacteria. FEMS Microbiology Letters 309:1-7.

922

923 Velićanski A, Cvetković D, Markov S, Others. 2013. Characteristics of Kombucha

924 fermentation on medicinal herbs from Lamiaceae family. Romanian Biotechnological Letters $925 \quad 18: 8034-8042$.

926

927 Viljoen BC. 2001. The interaction between yeasts and bacteria in dairy environments.

928 International Journal Of Food Microbiology 69:37-44.

929

930 Villarreal-Soto SA, Beaufort S, Bouajila J. 2018. Understanding kombucha tea fermentation: $931 \quad$ A review. Journal of Food Science 83: 580-588.

932

933 Wasielewski H, Alcock J, Aktipis A. 2016. Resource conflict and cooperation between

934 human host and gut microbiota: implications for nutrition and health. Annals of the New York 935 Academy of Sciences 1372:20-28. DOI: 10.1111/nyas.13118.

936 
937 Watawana MI, Jayawardena N, Gunawardhana CB, Waisundara VY. 2016. Enhancement of

938 the antioxidant and starch hydrolase inhibitory activities of king coconut water (Cocos

939 nucifera var. aurantiaca) by fermentation with kombucha "tea fungus." International Journal

$940 \quad$ Of Food Science \& Technology 51:490-498.

941

942 West SA, Griffin AS, Gardner A. 2007. Social semantics: altruism, cooperation, mutualism, 943 strong reciprocity and group selection. Journal of Evolutionary Biology 20:415-432. DOI:

$944 \quad 10.1111 /$ j.1420-9101.2006.01258.x.

945

946 West SA, Griffin AS, Gardner A, Diggle SP. 2006. Social evolution theory for

947 microorganisms. Nature Reviews. Microbiology 4:597-607. DOI: 10.1038/nrmicro1461.

948

949 Williams WS, Cannon RE. 1989. Alternative Environmental Roles for Cellulose Produced by $950 \quad$ Acetobacter xylinum. Applied And Environmental Microbiology 55:2448-2452.

951

952 Wolfe BE, Button JE, Santarelli M, Dutton RJ. 2014. Cheese rind communities provide 953 tractable systems for in situ and in vitro studies of microbial diversity. Cell 158:422-433.

954 DOI: $10.1016 /$ j.cell.2014.05.041.

955

956 Wolfe BE, Dutton RJ. 2015. Fermented foods as experimentally tractable microbial 957 ecosystems. Cell 161:49-55. DOI: 10.1016/j.cell.2015.02.034.

958

959 Wu W, Gai B-C, Ji B-P. 2004. Study on the Isolation and Identification of Microbes of 
$960 \quad$ Kombucha. Food Science 25:55-58.

961

962 Yamada Y, Yukphan P, Lan Vu HT, Muramatsu Y, Ochaikul D, Tanasupawat S, Nakagawa

963 Y. 2012. Description of Komagataeibacter gen. nov., with proposals of new combinations

964 (Acetobacteraceae). The Journal Of General And Applied Microbiology 58:397-404.

965

966 Yang L, Ji B-P, Zhou F, Yang Z-W, Li T. 2008. Study on Fermentation Conditions of

967 Kombucha Key Functional Bacteria. Food Science 6:029.

968

969 Zhang H, Zhang Z, Xin X. 2011. Isolation and identification of microorganisms from

970 kombucha fungus culture. Journal of Beijing Union University (Natural Sciences) 2:011 


\section{Table $\mathbf{1}$ (on next page)}

Over the course of kombucha fermentation, microbes cooperate and compete.

Many of these processes lead to products that have potential human uses as antiseptics and biomaterials. 


\begin{tabular}{|c|c|c|c|}
\hline $\begin{array}{c}\text { Stage of } \\
\text { Fermentation }\end{array}$ & $\begin{array}{l}\text { Competitive } \\
\text { Interactions }\end{array}$ & $\begin{array}{l}\text { Cooperative } \\
\text { Interactions }\end{array}$ & Human uses \\
\hline $\begin{array}{c}\text { Yeast produce } \\
\text { invertase }\end{array}$ & $\begin{array}{c}\text { Possible competition } \\
\text { over invertase }\end{array}$ & $\begin{array}{c}\text { Yeast producing } \\
\text { invertase as a } \\
\text { public good }\end{array}$ & $\begin{array}{c}\text { Invert sugar, various } \\
\text { fermentations }\end{array}$ \\
\hline $\begin{array}{c}\text { Yeast ferment } \\
\text { sugars into } \\
\text { ethanol }\end{array}$ & $\begin{array}{c}\text { Yeast inhibiting } \\
\text { competitors with ethanol }\end{array}$ & $\begin{array}{l}\text { Bacteria using } \\
\text { ethanol as nutrient }\end{array}$ & $\begin{array}{c}\text { Ethanol as an } \\
\text { antiseptic }\end{array}$ \\
\hline $\begin{array}{l}\text { Bacteria oxidize } \\
\text { and acidify } \\
\text { ethanol }\end{array}$ & $\begin{array}{l}\text { Bacteria inhibiting } \\
\text { competitors with } \\
\text { acidification }\end{array}$ & $\begin{array}{c}\text { Bacteria } \\
\text { metabolizing } \\
\text { ethanol as an } \\
\text { energy source }\end{array}$ & Acid as an antiseptic \\
\hline $\begin{array}{c}\text { Bacteria produce } \\
\text { biofilm }\end{array}$ & $\begin{array}{l}\text { Bacteria physically } \\
\text { blocking competitors and } \\
\text { creating anoxic } \\
\text { environment in liquid }\end{array}$ & $\begin{array}{l}\text { Spatially structuring } \\
\text { kin, possible } \\
\text { resource storage } \\
\text { and protection from } \\
\text { invading pathogens }\end{array}$ & $\begin{array}{l}\text { Biomaterial, possibly } \\
\text { one which protects } \\
\text { from invasion by } \\
\text { pathogens }\end{array}$ \\
\hline
\end{tabular}




\section{Figure 1}

Kombucha metabolism and microbial interactions.

(A) Kombucha is brewed by adding tea and table sugar to a small amount of kombucha starter which contains yeast and bacteria. These microbes begin to break down the sugar, leading to a metabolic cascade that ends with a bubbly, acidic and slightly alcoholic beverage. (B) During the process of fermentation, cooperative and competitive interactions occur among microbes. The production of the public good invertase by yeast, the removal of waste products through metabolization of alcohol and the generation of the cellulose pellicle by bacteria are potentially cooperative functions. Antimicrobial metabolites, low pH, and the generation of a physical barrier inhibit the growth of competitors. 
A

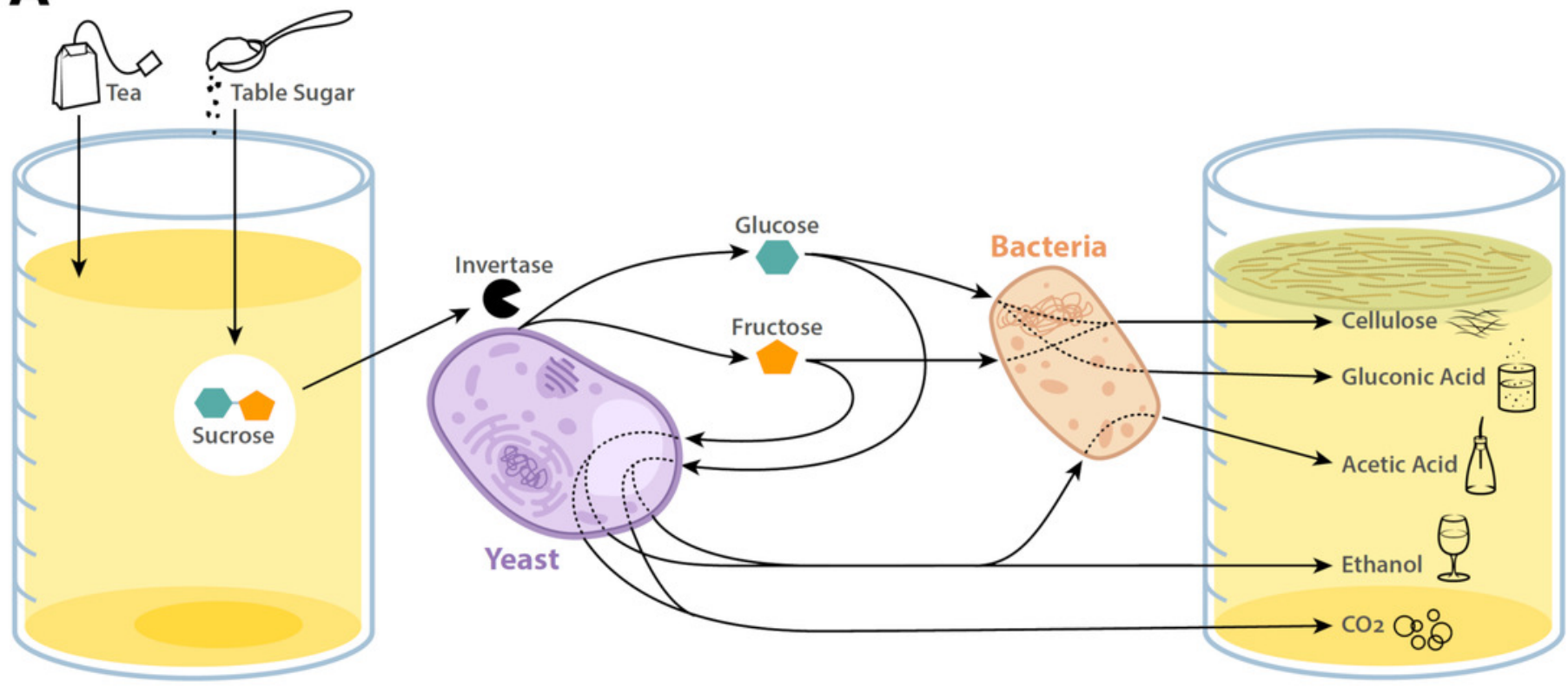

B

Cooperation
Public Goods

Waste Removal

Syntrophic Interactions
Spatial Structuring

Resource Storage

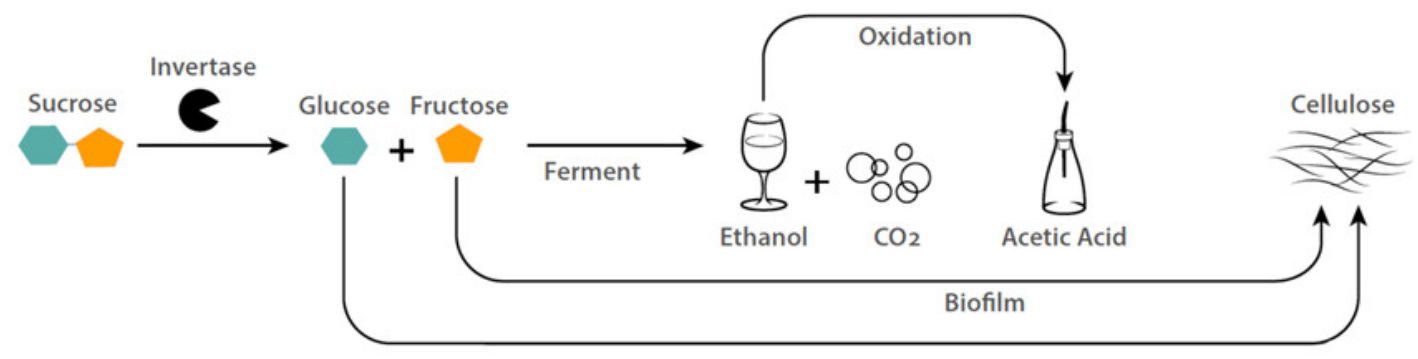

Competition

Inhibition of Invaders

Physical Barrier

Block Access to Oxygen 


\section{Figure 2}

Typical appearance of kombucha biofilm.

At the top of the image is the multi-species biofilm which is made up of Komagataeibacter hansenii, Dekkera bruxellensis, Dekkera anomala, and Schizosaccharomyces pombe. Often, pendulous 'strands' of material are seen dangling from the underside of the biofilm as they are in this image. The liquid underneath the biofilm is tea undergoing fermentation. 


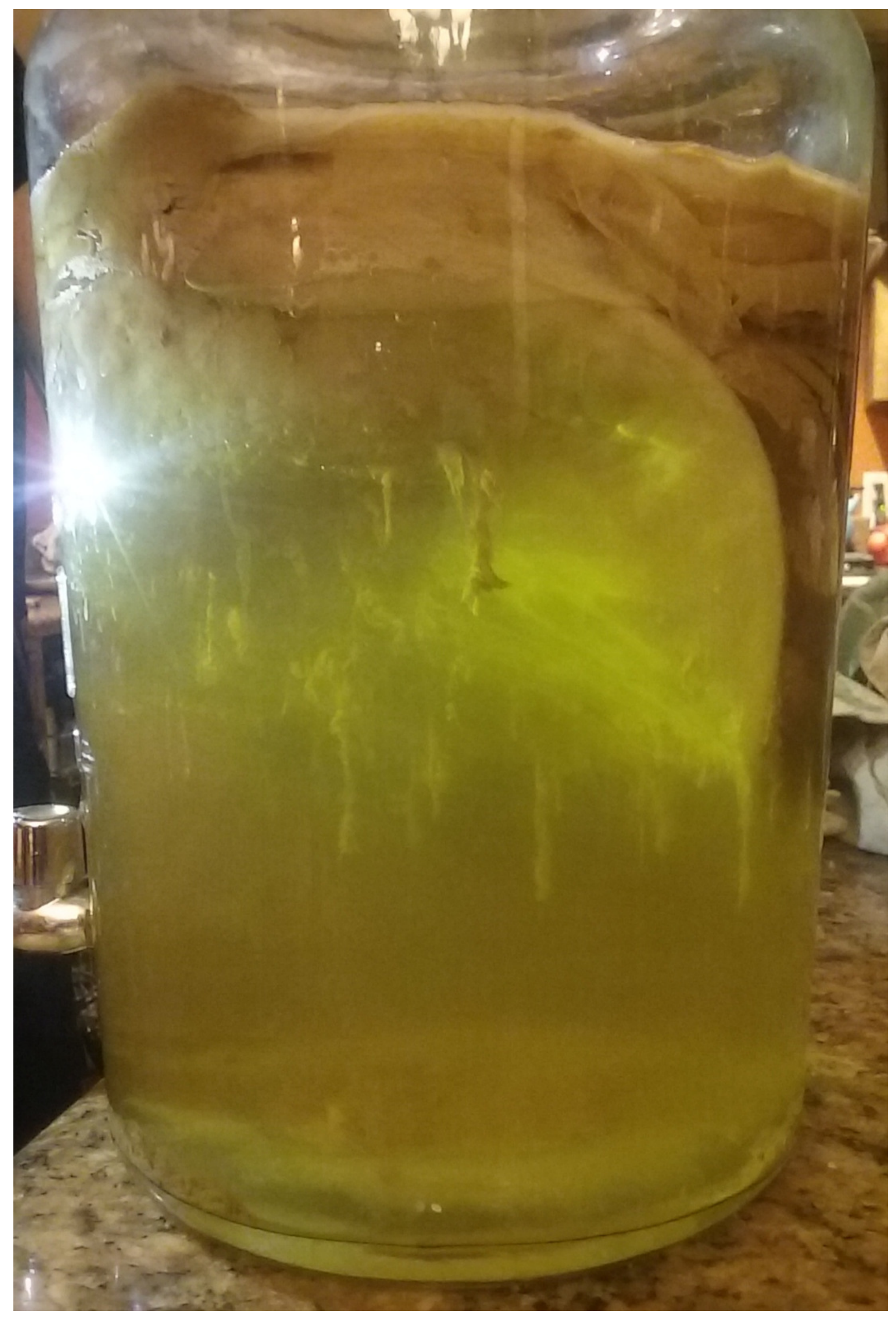

PeerJ reviewing PDF | (2018:09:31579:2:0:NEW 25 Jul 2019) 